\title{
EFFICIENCY ANALYSIS IN DIFFERENT TYPOLOGIES OF FARMING IN ITALIAN FADN DATASET
}

\author{
Nicola Galluzzo ${ }^{1}$
}

\section{Summary}

Italian farms are characterized by modest plots of usable agricultural area scattered in many rural villages. The purpose of this analysis was to assess by a quantitative method technical, economic and allocative efficiency in Italian farms over the time 20042013 in function of different typologies of farms (TF) and their own farm productive specialization. Hence, the main question of the paper has been to estimate if the farm's specialization in cultivating crops or in breeding livestock has influenced the efficiency of Italian farms. Findings have pointed out an important impact of financial subsidies allocated by the Common Agricultural Policy on the level of technical and economic efficiency; outcomes have also emphasized as a cut in costs of some inputs such as fertilizers and crops protection is essential in increasing efficiency in Italian farms.

Keywords: Common Agricultural Policy, typologies of farming, allocative efficiency, economic efficiency, Italy.

JEL: Q10, Q12, Q18

\section{Introduction}

Main findings in the most recent Italian Agricultural Census in 2000, 2010 and in the Eurostat database have emphasized as more than $90 \%$ of Italian farms has got an average amount in usable agricultural area lower than 10 hectares (Istat, 2012). Reasons of this growth in can been found in a significant decrease of agrarian enterprises as a consequence of an intensified process of exodus from the countryside because of the economic recession in 2008 and also because of a squeezing of farmer's income (Van der Ploeg et al., 2002). The typology of farms, in terms of farm's specialization in crops and or in breeding, and the location of farms have been two main factors influencing the level of farm's income and consequently the out rural emigration. Comparing outcomes in all other European countries, it emerges that more than 95\% of farms has got an usable agricultural size lower than 5 hectares (Festuccia, 2013; Istat, 2012). This value is far low to the European average of agrarian area equal to 12.6 hectares

1 Nicola Galluzzo, Ph.D., Director of Association of Geographic and Economic Studies in Rural Areas (ASGEAR), Via Salaria per L'Aquila no. 76 scala A, 02100 Rieti, Italy, Email: asgear@1ibero.it. 
(Greco and Di Cristofaro, 2011) and it arose significantly over the time due to the rural depopulation and emigration from the countryside. In order to contrast these downsides, the diversification in farm's activities has been one of the most useful action both to get better the farmer's income and also to restructure socio-economic relationships inside rural communities (Galluzzo, 2014; Van der Ploeg et al., 2000; Stockdale, 2006; 2004; Van der Ploeg, Renting, 2000; Shucksmith, Chapman, 1998)

Focusing the attention on Italy, ninety-five percent of Italian farms are owned by a sole agrarian entrepreneur, who has got both the absolute ownership of the farm and also the management of it with the same level of technical efficiency than the medium size farms as well as of other agrarian enterprises managed by limited companies (Galluzzo, 2013; 2015a). The typical context and features of the Italian agrarian socioeconomic fabric is made by small family farms, whose ownership is in the hands of a single person, who is the householder. These farms are predominately scattered in upland and in less favored rural areas hence, in these territories farmers are the main tile in the complex mosaic of multifunctionality such as a priority factor in the holistic rural development process able to reduce partially environmental degradation in a perspective of multifunctionality (Galluzzo, 2015b). As previously mentioned, findings on the analysis of efficiency and on the agricultural property have emphasized the role and function of smallholder farmers, that have got tiny units of production, mostly fragmented and located dispersedly in the Italian countryside considered wrongly because of their dimension, inefficient as assessed and argued in other European countries (Galluzzo, 2013; 2015a; Camelia, Vasile, 2016).

In literature many scholars have investigated before and after the enlargement of the European Union in 2004 the technical and economic efficiency, addressing their research attention on the nexus between efficiency and some variables such as level of farm net income, dimension of farm, crop specialization and financial subsidies allocated by the Common Agricultural Policy (Galluzzo, 2015a; 2016; Camelia, Vasile, 2016; Latruffe et al., 2004; Latruffe, 2013; Latruffe et al., 2005; Bojnec, Latruffe, 2008; Davidova, Latruffe, 2007; Bakucs et al., 2010; Latruffe et al., 2012; Guyomard et al., 2006; Bojnec, Latruffe, 2009; Bielik, Rajcaniova, 2004). Some of these latter authors have argued as a critical downside of smallholder farms is intrinsic in their small fragmentized poor plots of land which does not allow an efficient use of productive factors such as capital land and labor capital with no opportunities in reducing the cost of inputs by new investments. Other studies have deemed as big farms and medium sized ones should be considered more efficiently than small enterprises ones; in particular, if the ownership is in the hands of limited companies or cooperatives the level of assessed efficiency have been better than family small farms (Galluzzo, 2013; Camelia, Vasile, 2016). These latter farms are able to diversify their activities and to improve their income due to a high level of investments in technologies and to a highest level of labour capital and its intensity. Therefore, among variables such as property of farm, dimension of usable agricultural surface and economic and technical efficiency there is a positive correlation and a direct nexus (Bravo-Ureta et al., 2007). In the same 
time, few studies only have been addressed to investigate connections among typology of property and efficiency in the primary sector (Bravo-Ureta, Pinheiro, 1993; Chavas, Aliber, 1993; Galluzzo, 2016) underlining the role of farm size on the efficiency (van Zyl et al., 1996).

In order to assess the impact of the Common Agricultural Policy on farmers in different European Countries, the EU in the 1965, by the Council Regulation number 79, has established an analysis on a sample of farmers called Farm Accountancy Data Network (FADN). This is an annual survey which covers approximately 80,000 farms and a population of about 5,000,000 farmers located in the European Union equal to the $90 \%$ of usable agricultural area (UAA) and approximately $90 \%$ of the total European agricultural production (European Commission, 2014).

In many European countries, lots of studies have investigated in depth the efficiency using the Farm Accountancy Data Network dataset, focusing their target of study towards few specific investigations on a sample of European farms located in different nations (Veveris et al., 2007; Latruffe et al., 2012; Latruffe, Nauges, 2014; Galluzzo, 2015a; Cesaro et al., 2010; Bojnec, Latruffe, 2008). For other authors, the purpose of their studies has been addressed in assessing if there are some quantitative connections among several variables as farm size, cropping specialization, typology of farming and the level of technical and economic efficiency in different European countries comparing location of farms, such as altimetry, and their effect on the efficiency (Bojnec, Latruffe, 2007; Bielik, Rajcaniova, 2004; Latruffe et al., 2004; Cesaro et al., 2009; Cesaro et al., 2010).

In Italy, very few studies have investigated main correlations, using the FADN dataset, between the farm dimension and the technical and economic efficiency (Galluzzo, 2013; 2016) or among typology of farming, farm's location, and efficiency (Cesaro et al., 2010; Cesaro et al., 2009). Findings in small farms managed by only one farmer have pointed out as the small family farms are able to maximise the labour factor of production minimizing the economic and entrepreneurial risk by the diversification in agrarian process of cultivation using the workforce in a more efficiently way (Gorton, Davidova, 2004; Bojnec, Latruffe, 2007; Bielik, Rajcaniova, 2004; Latruffe et al., 2004). Farms by the diversification have reduced the socio-economic marginalization in territories at risk of rural emigration (Van der Ploeg et al., 2002; Van Der Ploeg, Renting, 2000) even if, in other European countries members of the EU, a mixed typology of farming activity, such as crops and breeding, has pointed out the poorest level of technical and economic efficiency (Galluzzo 2013; 2016).

\section{Aim of the research}

In literature review, lots of studies have investigated the role of family farm, size of farms and efficiency but hitherto few researches have been addressed in assessing the nexus between crop or breeding specialization and technical and economic efficiency (Galluzzo, 2015a; Morrison Paul et al., 2004; Cesaro et al., 2010; Latruffe et al., 2004; 2012).

EP 2017 (64) 2 (451-465) 
Comparing also limited company agrarian enterprises and agricultural cooperatives because of their own level of social capital endowment and the structure of their politic, managerial decisions, findings have pointed out a direct relationship among these typologies of farms and the context of productive specialization, which is able to act positively on the level of efficiency and maximization of output (Latruffe, 2010).

Lots of scholars have pointed out as there are relationships between farm size and the technical, economic efficiency by stratifying the sample of farms in function of the variable cropping specialization (Garcia et al., 1982) using a multi-output approach of investigation or a multi-input methodology (Bojnec, Latruffe, 2008). Focusing the attention on an analysis about the spatial and geographical diffusion of studies on the economic efficiency in farms, many of them have been carried out in developing countries (Bravo-Ureta, Pinheiro, 1993) and in some European countries using a parametric approach (Curtiss, 2000) with the purpose to investigate the role of crop specialization on the allocative and technical efficiency in farms.

The aim of this analysis has been to assess the technical, economic and allocative efficiency in a sample of small Italian farms belonging to the Farm Accountancy Data Network (FADN) from 2004 to 2013, stratifying them in 14 clusters in function of their typology of farming specialization (TF) on the base of the classification proposed by the European Commission Decision 369 promulgated in 2003.

The typology of farming grouping was: specialist COP (cereals, oilseed and protein crops), specialist other field crops, specialist horticulture, specialist vineyards, specialist orchards-fruits such as specialist fruit and citrus fruit, specialist olives (for example various permanent crops combined), specialist milk (milk and cattle rearing), specialist sheep and goats, specialist cattle as specialist cattle-rearing and fattening, cattle rearing, cattle fattening and cattle-dairying, rearing and fattening combined, specialist granivores (pigs and poultry), mixed crops, mixed livestock and mixed crops and livestock.

\section{Methodology}

In order to study the efficiency there are two methods: a parametric or deterministic approach, which needs a specific function of production and other parametric variables such as labor, land capital, agrarian capital and a non-parametric model or DEA (Data Envelopment Analysis). The DEA approach is aimed at defining in function of the distance from the frontier of a hypothetical function of production an index of technical inefficiency or technical efficiency (Bielik, Rajcaniova, 2004). Efficient farms are located along the hypothetical function of production; some of them outside this frontier are not efficient.

In the non-parametric model, some fluctuations from the frontier of the function of production are considered no efficient thus, the technical efficiency is described as a set of capabilities of farmers in maximizing the output minimizing in the same time the used inputs or vice versa (Bojnec, Latruffe, 2008). In this research, the efficiency has been 
estimated by a non-parametric model applied to specific assumptions of a constant return to scale or CRS in an input oriented model (Farrel, 1957; Battese, 1992; Coelli, 1996) using PIM-DEA software. Therefore, in this research a CRS approach has implied as an increase in all input has changed in the same proportion the produced output.

The purpose of DEA linear programming model is to minimize in a multipleoutput model the multiple-input in each farm that is a ratio of efficiency $(\mathrm{h})$ and in a mathematical model it can be written (Papadas, 1991):

$\max \mathrm{h}=\sum_{\mathrm{r}} \mathrm{u}_{\mathrm{r}} \mathrm{y}_{\mathrm{rjo}} / \sum_{\mathrm{i}} \mathrm{v}_{\mathrm{i}} \mathrm{x}_{\mathrm{ijo}}$

s.t.

$\sum_{\mathrm{r}} \mathrm{u}_{\mathrm{r}} \mathrm{y}_{\mathrm{rj}} / \Sigma_{\mathrm{i}} \mathrm{v}_{\mathrm{i}} \mathrm{x}_{\mathrm{ij}} \leq 1$

$\mathrm{j}=0,1, \ldots . . \mathrm{n}($ for all $\mathrm{j})$

$\mathrm{u}_{\mathrm{r}}, \mathrm{v}_{\mathrm{i}} \geq 0$

$\mathrm{u}_{\mathrm{r}}$ is the price vector of produced output

$\mathrm{y}_{\mathrm{rjo}}$ is the output level

$\mathrm{v}_{\mathrm{i}}$ is the input price vector for each used input

$\mathrm{x}_{\mathrm{ijo}}$ is the input level

In term of productivity if there are two farms, called also Decision Making Unit (DMUs), such as A and B able to produce two levels of output such as $\mathrm{y}_{\mathrm{a}}$ or $\mathrm{y}_{\mathrm{b}}$ using a specific quantity of input $\mathrm{x}_{\mathrm{a}}$ and $\mathrm{x}_{\mathrm{b}}$, the productivity is a simple ratio between produced output out and used input or rather a ratio $\mathrm{y}_{\mathrm{a}} / \mathrm{x}_{\mathrm{a}}$ and $\mathrm{y}_{\mathrm{b}} / \mathrm{x}_{\mathrm{b}}$.

The value of efficiency should be greater to 0 and lower than 1 ; any small but positive value of efficiency between these two extremes implies as none input and output can be ignored in estimating the efficiency pointing out which input or output have to be implemented in order to get better the technical or economic efficiency (Bhagavath, 2009; Galluzzo, 2013; 2016).

The non-parametric linear model throughout the Data Envelopment Analysis has been introduced for the first time in 1978 (Charnes et al., 1978) and it is useful to estimate the relative efficiency in each Decision Making Unit based on different level of input and output (Hadad et al., 2007) with the purpose to minimize the level of input in the process of production (Doyle, Green, 1994).

The goal of a non-parametric input oriented model, such as in our research, or DEA linear programming, is to minimize in a multiple-output model the multiple-input in each farm that is a ratio of efficiency. This model has lots of possible solutions and $u_{r}^{*}$ and $v_{i}^{*}$ are two variables able to solve the problem of efficiency in terms of price vector of produced output and the input price vector (Bhagavath, 2009; Papadas, 1991). If h is 1 or $100 \%$ there are not issues about the efficiency because this unit $\left(\mathrm{DMUh}_{1}\right)$ is the most efficient and in any case more efficient compared to other DMUh ${ }_{n}$, but whether $h$ EP 2017 (64) 2 (451-465) 
is above 100 there are lots of units more efficient than this unique and inefficient unit $\left(\mathrm{DMUh}_{1}\right)$ (Bhagavath 2009). To solve this negative aspect is fundamental to transform the model in a linear function by a linear programming methodology called CCR (Charnes, Cooper, 1962; Bhagavath, 2009) written in this way:

$\max \mathrm{h}=\sum_{\mathrm{r}} \mathrm{u}_{\mathrm{r}} \mathrm{y}_{\mathrm{rjo}}$

s.t. dual variable

$\Sigma_{\mathrm{i}} \mathrm{v}_{\mathrm{i}} \mathrm{X}_{\mathrm{ijo}}=100 \% \mathrm{Z}_{\mathrm{o}}$

$\sum_{\mathrm{r}} \mathrm{u}_{\mathrm{r}} \mathrm{y}_{\mathrm{rij}}-\Sigma_{\mathrm{i}} \mathrm{v}_{\mathrm{i}} \mathrm{x}_{\mathrm{ijo}} \leq 0$ with $\mathrm{j}=0,1, \ldots \mathrm{n}$ (for all $\mathrm{j}$ ) $\lambda_{\mathrm{j}}$

$-\mathrm{v}_{\mathrm{i}} \leq-\varepsilon \quad \mathrm{i}=0,1, \ldots \mathrm{m}$ and $\varepsilon$ is a positive value $\mathrm{s}_{\mathrm{i}}^{+}$

$\mathrm{u}_{\mathrm{r}} \leq-\varepsilon \quad \mathrm{r}=0,1, \ldots \mathrm{t}$ and $\varepsilon$ is a positive value $\mathrm{s}_{\mathrm{r}}^{-}$

$\lambda_{\mathrm{j}}$ are shadow prices able to reduce the efficiency in each unit lower than 1 or $100 \%$ and a positive value of $\lambda_{j}$ is able to assess a peer group in some inefficient unit.

In the dual problem, it is important to consider a dual variable in each constraint in the primary model (Charnes et al., 1978) but this paper did not take into account in the dual model a constraint able to classify and to discriminate DMUs using the super efficiency called A\&P model (Andersen, Petersen, 1993). In mathematical terms the solution of the dual model is written as:

$\min 100 \mathrm{Z}_{\mathrm{o}}-\varepsilon \Sigma_{\mathrm{i}} \mathrm{s}_{\mathrm{i}}^{+}-\varepsilon \Sigma_{\mathrm{r}} \mathrm{s}_{\mathrm{r}}^{-}$

s.t.

$\Sigma_{\mathrm{j}} \lambda_{\mathrm{j}} \mathrm{x}_{\mathrm{ij}}=\mathrm{x}_{\mathrm{ijo}} \mathrm{Zo}-\mathrm{s}_{\mathrm{i}}^{+} \mathrm{i}=0,1, \ldots \mathrm{m}$

$\sum_{\mathrm{j}} \lambda_{\mathrm{j}} \mathrm{x}_{\mathrm{rj}}=\mathrm{y}_{\mathrm{rj} 0}+\mathrm{s}_{\mathrm{r}}^{-} \quad \mathrm{r}=0,1, \ldots . \mathrm{t}$

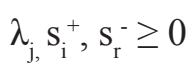

Table 1. Main results in Italian typologies of farming part of FADN dataset

\begin{tabular}{|l|c|c|c|}
\hline \multicolumn{1}{|c|}{$\begin{array}{c}\text { Type of } \\
\text { farming }\end{array}$} & $\begin{array}{c}\text { Technical } \\
\text { efficiency }\end{array}$ & $\begin{array}{c}\text { Cost } \\
\text { efficiency }\end{array}$ & $\begin{array}{c}\text { Allocative } \\
\text { efficiency }\end{array}$ \\
\hline Cattle & 87.3 & 20.71 & 23.72 \\
\hline $\begin{array}{l}\text { COP (cereals, oilseed and } \\
\text { protein crops) }\end{array}$ & 100 & 21.92 & 21.92 \\
\hline Fruits & 100 & 54.22 & 54.22 \\
\hline Granivores & 100 & 100 & 100 \\
\hline Horticulture & 100 & 37.57 & 37.57 \\
\hline Milk & 100 & 26.69 & 26.69 \\
\hline Mixed crops & 86.59 & 30.42 & 35.14 \\
\hline Mixed crops and livestock & 76.6 & 23.67 & 30.9 \\
\hline Mixed livestock & n.a. & n.a. & n.a. \\
\hline Olives & 100 & 35.93 & 35.93 \\
\hline
\end{tabular}




\begin{tabular}{|l|c|c|c|}
\hline Permanent crops combined & 99.9 & 42.48 & 42.53 \\
\hline Sheep and goats & 100 & 26.6 & 26.6 \\
\hline Specialized other & 100 & 28.18 & 28.18 \\
\hline Wine & 100 & 51.32 & 51.32 \\
\hline Total & $\mathbf{8 6 . 2 4}$ & $\mathbf{3 1 . 2 7}$ & $\mathbf{3 6 . 2 6}$ \\
\hline
\end{tabular}

Source: Author's elaboration on FADN dataset published on the website http://ec.europa.eu/ agriculture/rica/database/database_en.cfm

\section{Results and discussion}

Findings over the time of investigation, since 2004 to 2013, have pointed out in all Italian farms part of the FADN dataset the worst performances, which in average value considering all type of farming specialization has been close to $86 \%$ lower than the optimal value equal to $100 \%$ (Tab. 1).

Furthermore, both in term of cost efficiency and also in terms of allocative efficiency outcomes have been very poor with values of efficiency below $40 \%$ and in particular the cost efficiency has been more inefficient than the allocative one. Farms specialized in pig and poultry breeding have pointed out the highest level of technical, economical and allocative efficiency. By contrast agrarian enterprises specialized in cattle breeding (cattle-rearing and fattening) and in cereals, oilseed and protein crops (COP) have had the poorest level of efficiency.

Wine farms and farm specialized in fruit and orchards production have been efficient in technical terms but focusing the attention on the level of economic and allocative efficiency the value under $55 \%$ has been anyway inefficient because it is below the threshold of efficiency close to $100 \%$.

Input oriented analysis of the technical efficiency using the constant return to scale (CRS) and the variable return to scale (VRS) has pointed out the same outcomes in terms of efficiency (Tab. 2), even if the total value in all data has been lower $100 \%$ with positive results in most of typologies of farming with the exception of mixed crops and livestock which have had the poorest level in terms of technical efficiency.

Table 2. Main results of technical efficiency using the variable return to scale (VRS) and constant return to scale (CRS) in Italian farms part of the FADN dataset

\begin{tabular}{|l|c|c|}
\hline \multicolumn{1}{|c|}{$\begin{array}{c}\text { Typology of } \\
\text { farming }\end{array}$} & $\begin{array}{c}\text { Technical efficiency } \\
\text { VRS }\end{array}$ & $\begin{array}{c}\text { Technical efficiency } \\
\text { CRS }\end{array}$ \\
\hline Cattle & 87.3 & 87.3 \\
\hline COP (cereals, oilseed and protein crops) & 100 & 100 \\
\hline Fruits & 100 & 100 \\
\hline Granivores & 100 & 100 \\
\hline Horticulture & 100 & 100 \\
\hline Milk & 100 & 100 \\
\hline Mixed crops & 86.59 & 86.59 \\
\hline
\end{tabular}




\begin{tabular}{|l|c|c|}
\hline Mixed crops and livestock & 76.6 & 76.6 \\
\hline Mixed livestock & n.a. & n.a. \\
\hline Olives & 100 & 100 \\
\hline Permanent crops combined & 99.9 & 99.9 \\
\hline Sheep and goats & 100 & 100 \\
\hline Specialized other & 100 & 100 \\
\hline Wine & 100 & 100 \\
\hline Total & $\mathbf{8 6 . 2 4}$ & $\mathbf{8 6 . 2 4}$ \\
\hline
\end{tabular}

Source: Author's elaboration on FADN dataset published on the website http://ec.europa.eu/ agriculture/rica/database/database_en.cfm

In the early 1980s Banker, Charnes and Cooper proposed a model (BCC model) able to analyse the scale effect, as a consequence of some changes in the return to scale model, which are not constant, even if results in this research have been the same both in BCC and also in CCR approaches (Charnes, Cooper and Rhodes model); this latter methodology is a function similar to a straight line and it was proposed in 1978 by Charnes, Cooper and Rhodes in the case of constant return to scale applied in efficiency analysis.

Findings in the investigated model, comparing BCC and CCR approaches, have pointed out the best results in all investigated Italian typologies of farming specialization with the exception of farms specialized in cattle breeding, mixed crops and mixed crops and livestock (Tab. 3).

In general, in specialized agrarian enterprises have been pinpointed the best performances in technical efficiency both in CCR approach and also in BCC model; instead, farmers with mixed cultivations and livestock, due to a different use of labour capital and other investments in input, have had the poorest performances.

Table 3. Main results of technical efficiency comparing it to BCC and CCR efficiency model

\begin{tabular}{|l|c|c|c|}
\hline \multicolumn{1}{|c|}{$\begin{array}{c}\text { Typology of } \\
\text { farming }\end{array}$} & $\begin{array}{c}\text { Technical } \\
\text { efficiency }\end{array}$ & $\begin{array}{c}\text { BCC } \\
\text { efficiency }\end{array}$ & $\begin{array}{c}\text { CCR } \\
\text { efficiency }\end{array}$ \\
\hline Cattle & 100 & 87.3 & 87.3 \\
\hline COP (cereals, oilseed and protein crops) & 100 & 100 & 100 \\
\hline Fruits & 100 & 100 & 100 \\
\hline Granivores & 100 & 100 & 100 \\
\hline Horticulture & 100 & 100 & 100 \\
\hline Milk & 100 & 100 & 100 \\
\hline Mixed crops & 100 & 86.59 & 86.59 \\
\hline Mixed crops and livestock & 100 & 76.6 & 76.6 \\
\hline Mixed livestock & n.a. & n.a. & n.a. \\
\hline Olives & 100 & 100 & 100 \\
\hline Permanent crops combined & 100 & 99.9 & 99.9 \\
\hline Sheep and goats & 100 & 100 & 100 \\
\hline
\end{tabular}




\begin{tabular}{|l|c|c|c|}
\hline Specialized other & 100 & 100 & 100 \\
\hline Wine & 100 & 100 & 100 \\
\hline Total & $\mathbf{1 0 0}$ & $\mathbf{8 6 . 2 4}$ & $\mathbf{8 6 . 2 4}$ \\
\hline
\end{tabular}

Source: Author's elaboration on FADN dataset published on the website http://ec.europa.eu/ agriculture/rica/database/database_en.cfm

Peer findings show different efficient Decision Making Units in all investigated typologies of farming or rather these outcomes have underlined which type of farming specialization, in a comparing process, is a guide, described with the word true in the table 4, for other specialized Italian farms belonging to the FADN dataset.

Table 4. Peers findings in all investigated typologies of farming in FADN Italian dataset. False stands for no connections, true implies a role of guide of the typology of farming specialization.

\begin{tabular}{|c|c|c|c|c|c|c|c|c|c|}
\hline $\begin{array}{c}\text { Typology } \\
\text { of farming }\end{array}$ & $\mathrm{COP}$ & Fruits & Granivores & Horticulture & Milk & Olives & $\begin{array}{l}\text { Sheep } \\
\text { and } \\
\text { goats }\end{array}$ & $\begin{array}{c}\text { Specialized } \\
\text { other }\end{array}$ & Wine \\
\hline Cattle & False & False & True & False & True & False & True & False & True \\
\hline COP & True & False & False & False & False & False & False & False & False \\
\hline Fruits & False & True & False & False & False & False & False & False & False \\
\hline Granivores & False & False & True & False & False & False & False & False & False \\
\hline Horticulture & False & False & False & True & False & False & False & False & False \\
\hline \begin{tabular}{|l|} 
Milk \\
\end{tabular} & False & False & False & False & True & False & False & False & False \\
\hline $\begin{array}{l}\text { Mixed } \\
\text { crops }\end{array}$ & False & False & True & True & False & True & True & False & False \\
\hline $\begin{array}{l}\text { Mixed } \\
\text { crops and } \\
\text { livestock }\end{array}$ & False & False & True & True & True & False & True & False & False \\
\hline $\begin{array}{l}\text { Mixed } \\
\text { livestock }\end{array}$ & False & False & False & False & False & False & False & False & False \\
\hline Olives & False & False & False & False & False & True & False & False & False \\
\hline $\begin{array}{l}\text { Permanent } \\
\text { crops } \\
\text { combined }\end{array}$ & False & True & True & False & False & True & True & False & True \\
\hline $\begin{array}{l}\text { Sheep and } \\
\text { goats }\end{array}$ & False & False & False & False & False & False & True & False & False \\
\hline $\begin{array}{l}\text { Specialized } \\
\text { other }\end{array}$ & False & False & False & False & False & False & False & True & False \\
\hline Wine & False & False & False & False & False & False & False & False & True \\
\hline Total & False & True & True & False & True & False & True & False & True \\
\hline
\end{tabular}

Source: Author's elaboration on FADN dataset published on the website http://ec.europa.eu/ agriculture/rica/database/database_en.cfm 
Typology of farming such as granivores and sheep and goat specialized farms followed by wine and milk enterprises have had a guide role for lots of other typologies of farms such as cattle farms, mixed crops and other combined animals and crops (Tab. 4). In this case, if a type of farm specialization is efficient it is in the same time an enterprise able to lead other farms in a process of improvement of efficiency.

Four typologies of farm specialization out of 14 have pointed out some slacks, or rather an inefficient input or output allocation, even if focusing the attention on the whole typologies of farms findings have not been very positive in some inputs which should be increased such as labour input, cost for seeds and plants, fertilizers and crop protection (Tab. 5); in the same time, it is important to intensify financial subsidies allocated by the CAP, in particular assigning more financial resources in terms of payments in favour of disadvantaged rural areas.

Table 5. Slacks in some TFs investigated in Italian FADN dataset

\begin{tabular}{|l|c|c|c|c|c|c|}
\hline $\begin{array}{c}\text { Typology of } \\
\text { farming }\end{array}$ & $\begin{array}{c}\text { Labour } \\
\text { input }\end{array}$ & $\begin{array}{c}\text { Seeds and } \\
\text { plants }\end{array}$ & Fertilisers & $\begin{array}{c}\text { Crop } \\
\text { protection }\end{array}$ & $\begin{array}{c}\text { Other } \\
\text { crop } \\
\text { specific } \\
\text { costs }\end{array}$ & Machinery \\
\hline Cattle & $1,929.93$ & 86.29 & $37 . .15$ & 0 & 12.29 & 0 \\
\hline Mixed crops & $1,262.41$ & 0 & $1,099.95$ & 793.78 & 0 & 172.74 \\
\hline $\begin{array}{l}\text { Mixed crops } \\
\text { and livestock }\end{array}$ & $1,237.49$ & 4.72 & 780.01 & 521.53 & 0 & 267.57 \\
\hline $\begin{array}{l}\text { Permanent } \\
\text { crops combined }\end{array}$ & 872.22 & 211.84 & 197.67 & 617.86 & 0 & 105.45 \\
\hline \multicolumn{1}{|c|}{ Total } & $\mathbf{7 2 . 0 8}$ & $\mathbf{1 , 2 8 6 . 8 1}$ & $\mathbf{4 8 9 . 2 2}$ & $\mathbf{4 1 . 9 7}$ & $\mathbf{0}$ & $\mathbf{0}$ \\
\hline $\begin{array}{c}\text { Typology of } \\
\text { farming }\end{array}$ & $\mathbf{E n e r g y}$ & Taxes & $\mathbf{F a r m ~ N e t}$ & $\begin{array}{c}\text { Financial } \\
\text { subsidies } \\
\text { Income }\end{array}$ & $\begin{array}{c}\text { LFA } \\
\text { subsidies }\end{array}$ & payments \\
\hline Cattle & 0 & 207.15 & 0 & $4,696.92$ & 448.86 & 1064.44 \\
\hline Mixed crops & 171.79 & 0 & 0 & $2,950.14$ & 53.99 & 441.26 \\
\hline $\begin{array}{l}\text { Mixed crops } \\
\text { and livestock }\end{array}$ & 406.3 & 0 & 0 & $3,353.18$ & 0 & 320.19 \\
\hline $\begin{array}{l}\text { Permanent } \\
\text { crops combined }\end{array}$ & 0 & 0 & 0 & 44.82 & 5.34 & 0 \\
\hline Total & $\mathbf{0}$ & $\mathbf{0}$ & $\mathbf{0}$ & $\mathbf{1 , 3 0 1 . 7 7}$ & $\mathbf{1 0 3 . 6 1}$ & $\mathbf{9 1 . 1 8}$ \\
\hline
\end{tabular}

Source: Author's elaboration on FADN dataset published on the website http://ec.europa.eu/ agriculture/rica/database/database_en.cfm

Farms specialized in cattle breeding have underlined the need of reducing lots of inputs such as labour costs and costs correlated to the productive process such as fertilizers input in order to get better the efficiency in farms. Slacks assessed in this DEA input oriented model have not stressed any improvement in terms of output expressed as Farm Net Income in all investigated Italian farms. In general, farms with animals and mixed crops and livestock need a significant increase of financial subsidies allocated by the Common Agricultural Policy in order to increase their efficiency. 
Table 6. Gain in different input assessed in some typology of farming

\begin{tabular}{|l|c|c|c|c|}
\hline $\begin{array}{c}\text { Typology of } \\
\text { farming }\end{array}$ & $\begin{array}{c}\text { Labour input } \\
\mathbf{( \% )}\end{array}$ & $\begin{array}{c}\text { Seeds and } \\
\text { plants }\end{array}$ & $\begin{array}{c}\text { Fertilisers } \\
\mathbf{( \% )}\end{array}$ & $\begin{array}{c}\text { Crop protection } \\
\mathbf{( \% )}\end{array}$ \\
\hline Cattle & -53.71 & -21.22 & -16.3 & -12.7 \\
\hline Mixed crops & -59.08 & -13.41 & -65.92 & -68.12 \\
\hline $\begin{array}{l}\text { Mixed crops } \\
\text { and livestock }\end{array}$ & -61.67 & -23.69 & -65.56 & -69.79 \\
\hline $\begin{array}{l}\text { Permanent } \\
\text { crops combined }\end{array}$ & -33.33 & -54.78 & -19.67 & -42.31 \\
\hline \multicolumn{1}{|c|}{ Total } & $\mathbf{- 1 6 . 2 2}$ & $\mathbf{- 7 4 . 2 3}$ & $\mathbf{- 4 1 . 6 8}$ & $\mathbf{- 1 6 . 7}$ \\
\hline $\begin{array}{c}\text { Typology of } \\
\text { farming }\end{array}$ & $\begin{array}{c}\text { Machinery } \\
\mathbf{( \% )}\end{array}$ & $\begin{array}{c}\text { Energy } \\
\mathbf{( \% )}\end{array}$ & $\begin{array}{c}\text { Taxes } \\
\mathbf{( \% )}\end{array}$ & $\begin{array}{c}\text { Feed for grazing } \\
\text { livestock (\%) }\end{array}$ \\
\hline Cattle & -12.7 & -12.7 & -29.36 & -12.7 \\
\hline Mixed crops & -33.21 & -20.05 & -13.41 & -13.41 \\
\hline $\begin{array}{l}\text { Mixed crops } \\
\text { and livestock }\end{array}$ & -44.1 & -34.03 & -23.4 & -23.4 \\
\hline $\begin{array}{l}\text { Permanent } \\
\text { crops combined }\end{array}$ & -14.61 & -0.1 & -0.1 & -0.1 \\
\hline \multicolumn{1}{|c|}{ Total } & $\mathbf{- 1 3 . 7 6}$ & $\mathbf{- 1 3 . 7 6}$ & $\mathbf{- 1 3 . 7 6}$ & $\mathbf{- 1 3 . 7 6}$ \\
\hline
\end{tabular}

Source: Author's elaboration on FADN dataset published on the website http://ec.europa.eu/ agriculture/rica/database/database_en.cfm

In 4 typologies of farming specialization out of 14, findings have pointed out the need in reducing costs of seeds in particular in permanent combined crops; furthermore, a drop in the level of fiscal taxation is able to increase the level of efficiency in Italian farms (Tab. 6). In general, mixed agrarian enterprises have stressed the highest level of inefficiency due to high levels of farm's input cost.

\section{Conclusions}

Farm Accountancy Data Network is a useful tool in order to assess the impact of financial subsidies allocated by the Common Agricultural Policy and the level of efficiency on farms in function of their own productive specialization in terms of typology of farming. Despite the size of farms, the land capital is the main constraint in getting better the efficiency on farms; furthermore, findings have pointed out as more specialised are the farms higher are the levels of technical efficiency.

However, only Italian farms specialized in pig and poultry breeding have had the best performances both as economic efficiency and as allocative one. Findings have pointed out the need of intensifying financial payments allocated by the CAP and in particular some of them paid towards disadvantaged rural areas.

National and regional authorities have to support by the National Rural Development Plan measures and investment initiatives able to increase the level of capital land throughout some specific agreements of cultivation or breeding among farms with the 
aim of amortizing the costs of machinery, shrinking also, in a better way, the costs of cultivation. Summing up, this latter solution has the advantage of reducing the exodus from the countryside protecting in the same time the rural space in environmental terms as well, in particular after the economic recession in 2008 which has strongly lessened farmer's income.

\section{Literature}

1. Andersen, P., Petersen, N. (1993): A procedure for ranking efficient units in data envelopment analysis, Management Science, Vol. 39, No. 10, pp. 1261-1264.

2. Bakucs, L.Z., Latruffe, L., Fertő, I., Fogarasi, J. (2010): The impact of EU accession on farms' technical efficiency in Hungary, Post-communist economies, Vol. 22, No. 2, pp. 165-175.

3. Battese, G. E. (1992): Frontier production functions and technical efficiency: a survey of empirical applications in agricultural economics, Agricultural Economics. No. 7, pp. 185-208.

4. Bhagavath, V. (2009): Technical Efficiency Measurement by Data Envelopment Analysis: An Application in Transportation, Alliance Journal of Business Research (available at: www.ajbr.org).

5. Bielik, P., Rajcaniova, M. (2004): Scale efficiency of agricultural enterprises in Slovakia, Agric. Econ. Czech, Vol. 50, No. 8, pp. 331-335.

6. Bojnec, S., Latruffe, L. (2007): Farm size and efficiency: the case of Slovenia, In 100 ${ }^{\text {th }}$ Jubilee Seminar of European Association of Agricultural Economists "Development of Agriculture and Rural Areas in Central and Eastern Europe, (available at: https:// www.researchgate.net/publication/228653030).

7. Bojnec, Š., Latruffe, L. (2008): Measures of farm business efficiency, Industrial Management \& Data Systems, Vol. 108, No. 2, pp. 258-270.

8. Bojnec, Š., Latruffe, L. (2009): Determinants of technical efficiency of Slovenian farms, Post-Communist Economies, Vol. 21, No. 1, pp. 117-124.

9. Bravo-Ureta, B.E., Pinheiro, A.E. (1993): Efficiency analysis of developing country agriculture: A review of the frontier function literature, Agric. Resour. Econ. Rev., Vol. 22, pp. 88-101.

10.Bravo-Ureta, B.E., Solís, D., Moreira, V.H., Maripani, J.F., Thiam, A., Rivas, T.E., (2007): Technical efficiency 2007. Technical efficiency in farming: A metaregression analysis, J. Prod. Anal., Vol. 27, pp. 57-72.

11. Camelia, B., Vasile, B. (2016): The economic farm size and sustainable value disparities between Romania and the EU states, Annals-Economy Series, No. 1, pp. 50-57.

12.Cesaro, L., Marongiu, S., Zanoli, A., (2010): Analisi sull'efficienza e sui costi di produzione delle aziende zootecniche da latte in Italia. Confronto tra pianura e montagna, Atti del XLVII Convegno studi Sidea L'agricoltura oltre la crisi, Sidea. 
13.Cesaro, L., Marongiu, S., Arfini, F., Donati, M., Capelli, M.G. (2009): Methodology for Analysing Competitiveness, Efficiency, and Economy of Scale. Use and Application of DEA. Farm Accounting Cost Estimation and Policy Analysis of European Agriculture, FACEPA Deliverable No. D5.1.3 - April 2009, (available at: https://pdfs.semanticscholar.org/6e4e/2884132f2ea0304bbba50c1 abef00948adc5. pdf)

14.Charnes, A., Cooper, W.W. (1962): Programming with linear fractional functionals, Naval Research Logistics Quarterly, Vol. 9, No. 3-4, pp. 181-186.

15.Charnes, A., Cooper, W.W., Rhodes, E. (1978): Measuring the Efficiency of Decision Making Units, European Journal of Operational Research, Vol. 2, No. 6, pp. 429444.

16.Chavas, J.P., Aliber, M. (1993): An analysis of economic efficiency in agriculture: a nonparametric approach, Journal of Agricultural and Resource Economics, Vol. 18, No. 1, pp. 1-16.

17.Coelli, T. (1996): Recent developments in frontier modelling and efficiency measurement, Australian Journal of agricultural economics, Vol. 39, No. 3, pp. 219245.

18.Curtiss, J. (2000): Technical Efficiency and Competitiveness of the Czech agricultural Sector in late Transition - The Case of Crop Production, Paper presented at the KATO Symposium, Berlin, 2-4 November 2000, (available at www.academia. $\mathrm{edu} / 275094 /$ ).

19.Davidova, S., Latruffe, L. (2007): Relationships between technical efficiency and financial management for Czech Republic farms, Journal of Agricultural Economics, Vol. 58, No. 2, pp. 269-288.

20.Doyle, J., Green, R. (1994): Efficiency and cross-efficiency in DEA: derivations. meanings and uses, Journal of Operational Research Society, Vol. 45, No. 5, pp. 567-578.

21.European Commission Agriculture and Rural Development (2014): Concept of FADN. (available at www.ec.europa.eu/agriculture/rica/concept_en.cfm).

22.Farrell, M.O. (1957): The measurement of productive efficiency, Journal of Royal Statistical Society, Vol. 120, pp. 253-281.

23. Festuccia, A. (2013): In Italia e Romania la metà delle aziende agricole UE, Pianeta PSR, 17 (available at www.pianetapsr.it/flex/cm/pages/ServeBLOB.php/L/IT/ IDPagina/764)

24.Galluzzo, N. (2016): An analysis of the efficiency in a sample of small Italian farms part of the FADN dataset, Agric. Econ.-Czech, Vol. 62, pp. 62-70.

25.Galluzzo, N. (2015a): Technical and economic efficiency analysis on Italian smallholder family farms using Farm Accountancy Data Network dataset, Studies in Agricultural Economics, Vol. 117, No. 1, pp. 35-42.

26. Galluzzo, N. (2015b): Analysis of impact of rural development subsides on cropping 
specialization in Bulgaria and Romania using FADN data, $150^{\text {th }}$ EAAE Seminar "The spatial dimension in analysing the linkages between agriculture, rural development and the environment", Edinburgh, UK, October 22-23 2015, (available at http:// ageconsearch.umn.edu).

27. Galluzzo, N. (2014): The evolution of Italian farms and the role of subsidies paid by the European Union for rural development, Romanian Review of Regional Studies, Vol. 10, No. 1, pp. 79-88.

28.Galluzzo, N. (2013): Farm dimension and efficiency in Italian agriculture: a quantitative approach, American Journal of Rural Development, Vol. 1, No. 2, pp. 26-32.

29.Gorton, M., Davidova, S. (2004): Farm productivity and efficiency in the CEE applicant countries: a synthesis of results, Agricultural economics, Vol. 30, No. 1, pp. 1-16.

30.Greco, M., Di Cristofaro, E. (2011): Il settore agricolo attraverso i dati provvisori del VI Censimento generale dell'agricoltura, Agriregionieuropa: 7(26), (available at http://agriregionieuropa.univpm.it/content/article/31/26/il-settore-agricoloattraverso-i-dati-provvisori-del-6deg-censimento-generale).

31.Guyomard, H., Latruffe, L., Le Mouël, C. (2006): Technical efficiency, technical progress and productivity change in French agriculture: Do subsidies and farms' size matter?. In: Proceeding of $96^{\text {th }}$ EAAE Seminar, Tänikon, Switzerland, (available at: https://www.researchgate.net/publication/228378368).

32.Hadad, Y., Friedman, L., Hanani, M.Z. (2007): Measuring efficiency of restaurants using the data envelopment analysis methodology, Computer modelling and New Technologies, Vol. 11, No. 4, pp. 25-35.

33.Istat (2012): Caratteristiche strutturali delle aziende agricole. (available http:// www.istat.it/it/files/2011/03/1425-12_Vol_VI_Cens_Agricoltura_INT_CD_1_ Trimboxes_ipp.pdf)

34.Latruffe L., Nauges, C. (2014): Technical efficiency and conversion to organic farming: the case of France, European Review of Agricultural Economics, Vol. 41, No. 2, pp. 227-253.

35.Latruffe, L., Fogarasi, J., Desjeux, Y. (2012): Efficiency, productivity and technology comparison for farms in Central and Western Europe: The case of field crop and dairy farming in Hungary and France. Economic Systems, Vol. 36, No. 2, pp. 264278.

36.Latruffe, L. (2010): Competitiveness, productivity and efficiency in the agricultural and agri-food sectors, OECD Food, Agriculture and Fisheries Working Papers, No. 30, OECD Publishing, (available at: http://dx.doi.org/10.1787/5km91nkdt6d6-en)

37.Latruffe, L., Balcombe, K., Davidova, S., Zawalinska, K. (2005): Technical and scale efficiency of crop and livestock farms in Poland: does specialization matter?, Agricultural economics, Vol. 32, No. 3, pp. 281-296. 
38.Latruffe, L., Balcombe, K., Davidova, S., Zawalinska, K. (2004): Determinants of technical efficiency of crop and livestock farms in Poland, Applied economics, Vol. 36, No. 12, pp. 1255-1263.

39.Morrison Paul, C.J., Nehring, R., Banker, D. (2004): Productivity, Economies, and Efficiency in US Agriculture: A look at contracts, American Journal of Agricultural Economics, Vol. 86, No. 5, pp. 1308-1314.

40.Papadas, C.T. (1991): Technical efficiency and farm size: a non-parametric frontier analysis. In: (ed) University of Minnesota. Institute of agriculture. forestry and home economics. Staff Paper series P91-53 (available at www.purl.umn.edu/13679).

41.Shucksmith, M., Chapman, P. (1998): Rural development and social exclusion, Sociologia Ruralis, Vol. 38, No. 2, pp. 225-242.

42.Stockdale, A. (2004): Rural Out-Migration: Community Consequences and Individual Migrant Experiences, Sociologia Ruralis, Vol. 44, No. 2, pp. 167-194.

43. Stockdale, A. (2006): Migration: Pre-requisite for rural economic regeneration? Journal of Rural Studies, Vol. 22, No. 3, pp. 354-366.

44.Van Der Ploeg, J.D., Renting, H. (2000): Impact and potential: a comparative review of European rural development practices, Sociologia ruralis, Vol. 40, No. 4, pp. 529-543.

45.Van der Ploeg, J.D., Renting, H., Brunori, G., Knickel, K., Mannion, J., Marsden, T., De Roest, K, Sevilla-Guzman, E., Ventura, F. (2000): Rural development: from practices and policies towards theory, Sociologia ruralis, Vol. 40, No. 4, pp. 391408.

46. Van der Ploeg, J.D., Long, A., Banks, J. (2002): Living Countrysides: Rural Development Processes in Europe: the State of the Art, ISBN 9054391170, Elsevier EBI, Doetinchem.

47. Van Zyl, J., Miller, B.M. and Parker, A. (1996): Agrarian structure in Poland. The myth of large-farm superiority, Policy research working paper 1596. Washington: The World Bank, pp. 1-52.

48. Veveris A., Leimane I., Krievina A., (2007): Efficiency analysis of agricultural sector in Latria compared to other EU countries, based on FADN data, Economic science for rural development, Vol. 12, pp. 13-19. 